\title{
EFFECT OF DIFFERENT PLANT DENSITIES ON GROWTH PARAMETERS AND DRY MATTER ACCUMULATION IN COTTON (Gossypium hirsutum L.)
}

\author{
BEyYAVAS, V. - HALILOGLU, H.* \\ Department of Field Crops, Faculty of Agriculture, Harran University, Osmanbey Campus, \\ Sanliurfa 63050, Turkey \\ *Corresponding author \\ e-mail: haliloglu@harran.edu.tr; phone: +90-530-205-0794 \\ (Received $10^{\text {th }}$ May 2021; accepted $30^{\text {th }}$ Aug 2021)
}

\begin{abstract}
This study was carried out to determine the effects of various plant densities on growth parameters and dry matter accumulation in cotton (Gossypium hirsutum L.). Field experiments was conducted on the experimental site of Field Crops Department in Faculty of Agriculture, University of Harran. The Stoneville-453 cotton variety was used as plant material. Experimental layout was randomized blocks with 3 replications in the two years of experiment. Plant densities (PD) were $70 \times 5$ $\mathrm{cm}\left(\mathrm{PD} 1,28\right.$ plants per $\left.\mathrm{m}^{2}\right), 70 \times 20 \mathrm{~cm}\left(\mathrm{PD} 2,7\right.$ plants per $\left.\mathrm{m}^{2}\right)$ and $35 \times 5 \mathrm{~cm}\left(\mathrm{PD} 3,57\right.$ plants per $\left.\mathrm{m}^{2}\right)$. Plant height $(\mathrm{cm})$, number of nodes (pieces), height to nod ratio (HNR, piece), stem diameter $(\mathrm{cm})$, stem dry matter accumulation $(\mathrm{g})$, leaf dry matter accumulation $(\mathrm{g})$, flower dry matter accumulation $(\mathrm{g})$, total dry matter accumulation ( $\mathrm{g}$ ), number of leaves (pieces), leaf area index (LAI) at $60^{\text {th }}, 75^{\text {th }}, 90^{\text {th }}, 105^{\text {th }}$ and $120^{\text {th }}$ days from sowing and yields during harvest period were determined. The plant height, number of nodes, stem diameter, flower, leaf, stem and total dry matter accumulation weights were higher in the PD2 treatment, while LAI and yields were higher in PD3 treatment.
\end{abstract}

Keywords: biomass, leaf area index, management factors, row spacing, high yield formation

\section{Introduction and literature review}

Genetic potential of a variety, environmental conditions and cultural processes in crop production are the major factors affecting crop yield. Plant density in cotton cultivation is one of the most important variables affecting yield per unit area and increasing profitability. Proper plant density and fertilizer management are the most important factors to obtain high cotton yield (Bednarz et al., 2006; Tariq et al., 2018). Previous studies revealed that extreme high or low plant density causes a significant decrease in cotton yield. The cotton is extremely responsive to management factors, therefore, optimum density of cotton plants may vary depending on location, environment, cultivar and preferences of growers (Silvertooth et al., 1999; Dong et al., $2006 \mathrm{a}, \mathrm{b})$. However, the final lint yield of cotton was reported as stable across a wide range of plant population densities (Bednarz et al., 2000; Siebert et al., 2006).

Some studies reported that fiber yield increases with higher plant density per unit area (Mao et al., 2015) and plant density has a positive effect on yield increase (Zhi et al., 2016), while some studies indicated that plant density has no impact on cotton yield (Ren et al., 2013). Optimum plant density is a key determinant of high yield formation in cotton. The growth and development of plants can provide a beneficial micro-environment (canopy temperature, relative humidity and light transmittance) for high yield (Yang et al., 2014).

Kerby et al. (1990) reported that the dry matter content during the first squaring, first flowering, peak blooming and boll opening periods was higher under 
increased plant densities. In addition, leaf area index, dry matter accumulation and the number of bolls per unit area increased with decreasing row spacing (Samani et al., 1999).

The density of cotton population significantly affects layout of canopy, interception of light and eventually development of bolls. In addition, plant height, photosynthetic efficiency of leaves, plant architecture and boll sizes are also affected by number of plants per unit area (Hussain et al., 2000; Siebert et al., 2006). Lint yield and leaf area index increase with the increase in plant density, however, leaf area of single leaves is reduced (Gwathmey and Clement, 2010).

Distribution of assimilates between vegetative and reproductive organs has a significant impact on cotton yield (Reta-Sánchez and Fowler, 2002; Jones et al., 1996; Kerby et al., 1993). Studies indicating the importance of biomass accumulation and its distribution among reproductive organs for cotton yield (Saleem et al., 2010; Bange and Milroy, 2004; Wells and Meredith, 1984) were mostly carried out under extensive agricultural practices and using non-transgenic cotton varieties.

Production of high amount of biomass is needed for cotton yield and ratio of biomass among reproductive organs affects the cotton yield (Bange and Milroy, 2004). The cotton plants accumulate high vegetative biomass. The accumulation of biomass increases in early growth stages with the availability of more light to lower parts (Khan et al., 2020), while it decreases in the last growth stages due to shedding of fruits and leaves (Zhi et al., 2016; Khan et al., 2017).

Leaf area or leaf area index is considered an important indicator of growth, which is defined as the net increase in dry matter content for unit leaf area at unit time. The plant leaf area depends on the number of leaves on a plant, the average single leaf area, and the photosynthetic functional length of the leaves. The effects of these three features on the leaf area may vary depend on genetic structure of the variety and environmental conditions (Reddy and Reddy, 1992). The increase in leaf area index of cotton plants is slow in the first periods of the growing period, while increases rapidly later and can reach the highest level at the growing period of about 100 days (Wullschleger and Oosterhuis, 1992). The LAI which generally varies between 3.7 and 5.2, gradually decreases in later periods due to the leaf losses caused by the increase in the generative development of plants and leaf aging (Reta-Sánchez and Fowler, 2002).

Even though this study was conducted in 2006 and 2007 years, plant densities related to inter-row and intra-row spacings differ from region to region and machine or manual harvesting types in cotton cultivation areas. For this reason, this study still maintains its importance.

This study was carried out to determine the effects of different plant densities on the growth parameters of cotton and the changes in dry matter accumulation until harvest.

\section{Materials and methods}

Stoneville-453 cotton variety (Gossypium hirsutum L.) was used as plant material in the study. The Stoneville-453 cotton variety was breed by the Stoneville Seed Company and registered in 1988 (Calhoun et al., 1997). The variety, certified to be used in the Sanliurfa region in 1995, is preferred by farmers, especially due to medium early and high gin efficiency (42\%) (Harem, 2010). 


\section{Experimental site}

Field experiments were conducted in Eyyubiye Campus of Harran University, and the experimental site is located in Harran Plain, Sanliurfa $\left(37^{\circ} 08^{\prime}\right.$ North and $38^{\circ} 46^{\prime}$ east, ASL $465 \mathrm{~m}$ ) close to Syrian border in Turkey (Fig. 1).

Average temperature values during cotton growth period (April-November) in 2006 was between 11.4 and $33.4{ }^{\circ} \mathrm{C}$ and it was between 12.6 and $34.0{ }^{\circ} \mathrm{C}$ in 2007 . Total precipitation in 2006 (April-November) varied from 0 to $81.1 \mathrm{~mm}$, while it varied from 0 to $49.2 \mathrm{~mm}$ in 2007 (Table 1).

Table 1. Some important meteorological data of the experimental field (Anonymous, 2007b)

\begin{tabular}{c|c|c|c|c|c|c}
\hline Months & Years & $\begin{array}{c}\text { Av. max } \\
\text { temp. }\left({ }^{\circ} \mathbf{C}\right)\end{array}$ & $\begin{array}{c}\text { Av. min } \\
\text { temp. }\left({ }^{\circ} \mathbf{C}\right)\end{array}$ & $\begin{array}{c}\text { Av. temp. } \\
\left({ }^{\circ} \mathbf{C}\right)\end{array}$ & $\begin{array}{c}\text { Av. relative } \\
\text { humidity }\left({ }^{\circ} \mathbf{C}\right)\end{array}$ & $\begin{array}{c}\text { Av. total } \\
\text { precip. }(\mathbf{m m})\end{array}$ \\
\hline \multirow{4}{*}{ April } & First year & 23.2 & 12.3 & 17.8 & 62.9 & 81.1 \\
& Second year & 18.8 & 8.8 & 13.1 & 66.5 & 49.2 \\
& Long term averages & 22.0 & 10.0 & 15.9 & 56.0 & 49.2 \\
\hline \multirow{4}{*}{ May } & First year & 30.4 & 16.9 & 23.8 & 45.9 & 17.4 \\
& Second year & 31.1 & 19.5 & 25.4 & 54.0 & 8.8 \\
& Long term averages & 28.6 & 15.0 & 22.0 & 45.0 & 26.0 \\
\hline \multirow{5}{*}{ June } & First year & 38.0 & 22.8 & 30.8 & 40.8 & 0.3 \\
& Second year & 37.2 & 23.0 & 30.4 & 36.9 & 0.8 \\
& Long term averages & 34.4 & 20.2 & 27.9 & 32.4 & 3.0 \\
\hline \multirow{5}{*}{ Augusty } & First year & 38.5 & 24.9 & 32.2 & 45.5 & 0.3 \\
& Second year & 40.8 & 27.0 & 34.0 & 31.3 & 8.0 \\
& Long term averages & 38.6 & 26.8 & 33.1 & 29.7 & 0.6 \\
\hline \multirow{5}{*}{ September } & First year & 40.4 & 26.0 & 33.4 & 44.6 & - \\
& Second year & 39.3 & 25.4 & 32.2 & 41.9 & 3.2 \\
& Long term averages & 38.1 & 23.6 & 31.2 & 32.3 & 0.9 \\
\hline \multirow{5}{*}{ October } & First year & 32.3 & 22.4 & 27.2 & 42.3 & - \\
& Second year & 36.0 & 22.0 & 28.4 & 36.4 & - \\
& Long term averages & 33.8 & 19.8 & 26.7 & 35.1 & 1.1 \\
\hline & First year & 25.9 & 12.8 & 20.6 & 61.5 & 42.5 \\
& Second year & 28.4 & 16.5 & 21.6 & 47.7 & 25.9 \\
& Long term averages & 26.9 & 14.2 & 20.1 & 44.8 & 23.8 \\
\hline & First year & 16.3 & 7.7 & 11.4 & 57.5 & 26.2 \\
& Second year & 18.3 & 8.6 & 12.6 & 58.2 & 15.4 \\
& Long term averages & 18.6 & 8.3 & 12.8 & 59.0 & 45.7 \\
\hline
\end{tabular}

The soil of experimental field is alluvial, deep, and high in lime and potassium, while, poor in phosphorus content. Soil samples were taken from a depth of $0-20 \mathrm{~cm}$ in 2006 and 2007 before planting.

The clay content of the soil samples were 56.50 and $59.04 \%, \mathrm{pH}$ value was 7.76 and 7.66, organic matter content was 1.59 and $1.45 \%$, and lime content was 25.4 and $23.7 \%$, respectively (Table 2$)$. 


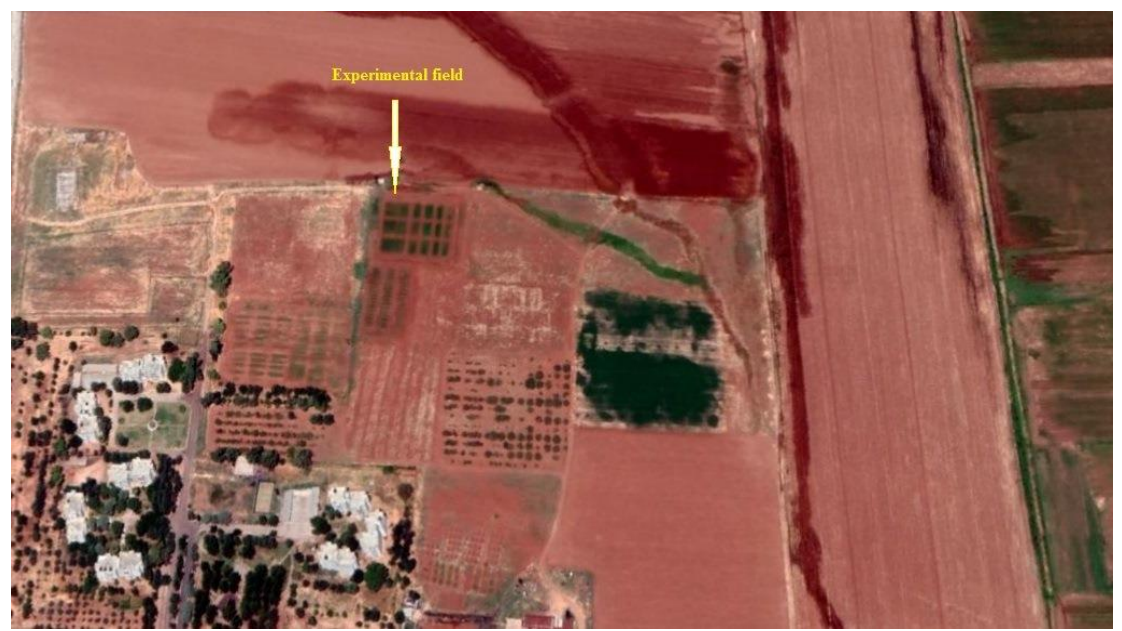

Figure 1. The map of the experimental field

Table 2. Some physical and chemical soil properties of the experimental field (Anonymous, 2007a)

\begin{tabular}{c|c|c}
\hline Soil properties & First year & Second year \\
\hline Clay (\%) & 56.50 & 59.04 \\
Silt-loam (\%) & 22.70 & 22.72 \\
Sand (\%) & 20.80 & 18.24 \\
pH & 7.76 & 7.66 \\
Lime $\left(\mathrm{CaCO}_{3}\right)(\%)$ & 25.40 & 23.70 \\
Total salt $(\%)$ & 0.052 & 0.068 \\
Organic matter $(\%)$ & 1.59 & 1.45 \\
\hline
\end{tabular}

\section{Experimental design}

Cotton seeds were planted on May 15 in 2006 and 2007. The experiment was conducted as a completely randomized block design with three replications. Each plot consisted of 4 rows with $10 \mathrm{~m}$ length. The plots were fertilized to provide $160 \mathrm{~kg} \mathrm{~N} \mathrm{ha}^{-1}$ and $80 \mathrm{~kg} \mathrm{P} \mathrm{ha}^{-1}$ phosphorus. Half of nitrogen and all of phosphorus were applied using 20.20.0 compound fertilizer during planting and the other half of nitrogen was applied using ammonium nitrate $(33 \% \mathrm{~N})$ fertilizer at the beginning of flowering.

Traditionally, $70 \times 20 \mathrm{~cm}$ of planting density is applied in the region where the experiments were carried out. In this study, different planting densities applied so as to determine interactions of the yield and some growth parameters with plant densities.

Following the sufficient emergence, the number of plants were decreased to arrange plant density to $70 \times 5 \mathrm{~cm}\left(\mathrm{PD} 1,28\right.$ plants $\left.\mathrm{m}^{-2}\right), 70 \times 20 \mathrm{~cm}\left(\mathrm{PD} 2,7\right.$ plants $\left.\mathrm{m}^{-2}\right)$ and $35 \times 5 \mathrm{~cm}$ (PD3, 57 plants $\mathrm{m}^{-2}$ ) (Fig. 2). Total of $900 \mathrm{~mm}$ irrigation water was applied in 2006 and 2007 with 9 furrow irrigations. All necessary agricultural practices during growing periods were carried out conventionally. Aphids (Aphiss gossypii), leafhopper (Empoasca spp), silverleaf whitefly (Bemisia tabaci Genn.) and cotton bollworm (Heliothis armigera Hübn.) were observed in 2006 and 2007; therefore, pesticides were applied considering the economic damage thresholds. Against aphids (Aphiss gossypii) insecticide (40\% Dimethoate active substance) with dose of $1000 \mathrm{cc} \mathrm{ha}^{-1}$, against 
leafhopper (Empoasca ssp) and whitefly (Bemisia tabaci Genn) $200 \mathrm{~g} \mathrm{ha}^{-1}$ of Acetamiprid and $600 \mathrm{cc} \mathrm{ha}^{-1}$ of Esfenvalerate, and against greenworm (Heliothus armigera Hübn.) $200 \mathrm{~g} \mathrm{ha}^{-1}$ of Acetamiprid and $2000 \mathrm{cc} \mathrm{ha} \mathrm{h}^{-1}$ of Cloropyrifos were mixed and applied.

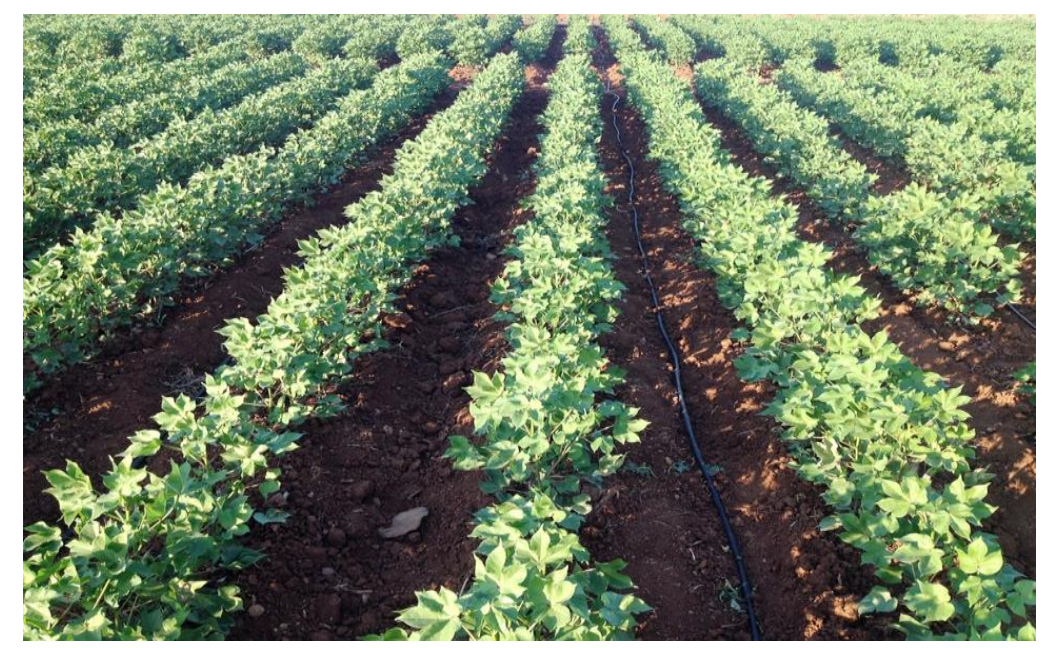

Figure 2. An image from the experiment field

\section{Cotton plant growth parameters}

The plant height, stem diameter, leaf number, number of nodes, height to node ratio (HNR) and leaf area index (LAI) of randomly selected 10 plants from each plot were determined at 60 (T1), 75 (T2), 90 (T3), 105 (T4) and 120 (T5) days after planting (DAP) according to Montgomery (1997).

\section{Biomass accumulation and partitioning}

These plants were then separated into three parts as reproductive structures (flowers), leaves and stems, and dried separately. Total dry matter weights were calculated by summing the dry matter weights of plant parts. Samples were oven dried at $70{ }^{\circ} \mathrm{C}$ for $72 \mathrm{~h}$ until attaining a constant weight (Wells and Meredith, 1986; Kandil et al., 2004).

Daily dry matter production was calculated using the following equation explained by Board (2000):

$$
\mathrm{BBO}=\mathrm{W} 2-\mathrm{W} 1 / \mathrm{T} 1-\mathrm{T} 2
$$

W1: Dry weight of plants at T1 $\left(\mathrm{g} \mathrm{plant}^{-1}\right), \mathrm{W} 2$ : Dry weight of plants at T2 $\left(\mathrm{g} \mathrm{plant}^{-1}\right)$, T1: The time when the dry matter weight determined during the first growing period (day), T2: The time when the dry matter weight determined during the second growing period (day).

\section{Leaf area index (LAI)}

Leaf area index was calculated using the following equation explained by Board (2000):

Leaf area index $(\mathrm{LAI})=$ total leaf area of plant $\left(\mathrm{cm}^{2}\right) /$ total area covered by a plant $\left(\mathrm{cm}^{2}\right)$ 


\section{Seed cotton yield}

The yields for experimental plots were determined by harvesting two rows in the middle after removing $1 \mathrm{~m}$ on each side to remove edge effect. Seed cotton yield per hectare was calculated using the mean yield value obtained for plots.

\section{Data analysis}

The field experiment was conducted in randomized block design, however, the data obtained for plant growth parameters except the seed cotton yield were analyzed in the statistical program of MINITAB 18.1 according to the split plots in the randomized blocks. The averages were grouped using the Tukey-HSD test.

\section{Results and discussion}

Variance analysis indicated a significant difference between years; therefore, the data of each year were presented separately.

\section{Plant height (cm)}

The highest plant height in $2006(78.71 \mathrm{~cm})$ was obtained in the PD2 plant density treatment, while the highest plant height in 2007 was recorded in PD1 and PD3 plant densities $(65.97 \mathrm{~cm}$ and $65.30 \mathrm{~cm})$. In the first year of the field experiment, the plant height decreased in parallel with the increase in plant density per $\mathrm{m}^{-2}$ (Table 3). The results recorded in the first year are in accordance with findings of Khan et al. (2020), Clawson et al. (2006) and Gwathmey and Clement (2010) who reported a decrease in plant height with the increase in plant density. In contrast to the plant heights in the first year, plant height increased with the increase in plant density in the second year. Similar to the results of second year, Kaggwa-Asiimwe et al. (2013) and Beyyavas et al. (2018) also indicated an increase in plant height with the increase in plant density. The differences in relationship between plant height and plant density may be attributed to the differences in climate and environmental conditions of the experimental sites.

The highest plant height in 2006 during plant growth period examined was reached at T5 $(97.14 \mathrm{~cm})$ and in 2007 at T4 and T5 times $(78.42 \mathrm{~cm}$ and $79.65 \mathrm{~cm})$. The cotton plant has an indeterminate growth habit (Tariq et al., 2018), therefore, the plant height regularly increases with the progress in time.

\section{Number of nodes (pcs plant ${ }^{-1}$ )}

The highest number of nodes in 2006 and 2007 was obtained in PD2 plant density (17.34 and 14.90 pcs plant $\left.^{-1}\right)$. Our findings are consistent with the findings of Clawson et al. (2006) and Gwathmey and Clement (2010) who reported that wide row distance in cotton cultivation increased the number of nodes per plant.

The highest number of nodes per plant in both years (18.81 and 17.83 pcs plant $^{-1}$ ) was recorded in at T5 time (Table 3). Since cotton has an indeterminate growth pattern, the number of nodes is increasing proportionally with increase in plant height.

The number of nodes vary according to genetics of the plant, fertilization, irrigation and cultural practices. In particular, excessive nitrogen fertilization and irrigation applications may cause an increase in plant height and, as a result, an increase in the number of nodes. 
Table 3. The effect of different plant densities and growth times in cotton on plant height $(\mathrm{cm})$, number of nodes ( $p c s$ plant $\left.{ }^{-1}\right)$, height to node ratio (HNR) and stem diameter $(\mathrm{cm})$

\begin{tabular}{|c|c|c|c|c|c|c|c|c|c|}
\hline \multirow[t]{2}{*}{ Treatments } & & \multicolumn{2}{|c|}{$\begin{array}{c}\text { Plant height } \\
(\mathbf{c m})\end{array}$} & \multicolumn{2}{|c|}{$\begin{array}{c}\text { Number of nodes } \\
\left(\text { pcs plant }^{-1}\right)\end{array}$} & \multicolumn{2}{|c|}{$\begin{array}{l}\text { Height to node } \\
\text { ratio (HNR) }\end{array}$} & \multicolumn{2}{|c|}{$\begin{array}{c}\text { Stem diameter } \\
(\mathrm{cm})\end{array}$} \\
\hline & & 2006 & 2007 & 2006 & 2007 & 2006 & 2007 & 2006 & 2007 \\
\hline \multirow{3}{*}{ Plant density } & PD1 & $75.22^{b^{*}}$ & $65.97^{\mathrm{a}^{*}}$ & $15.64^{b^{*}}$ & $14.14^{b^{*}}$ & $4.72^{\mathrm{a}^{*}}$ & $4.63^{\mathrm{a}^{*}}$ & $0.81^{b^{*}}$ & $0.71^{b^{*}}$ \\
\hline & PD2 & $78.71^{a}$ & $63.07^{b}$ & $17.34^{\mathrm{a}}$ & $14.90^{\mathrm{a}}$ & $4.47^{b}$ & $4.20^{b}$ & $1.11^{\mathrm{a}}$ & $1.43^{\mathrm{a}}$ \\
\hline & PD3 & $74.58^{b}$ & $65.30^{\mathrm{a}}$ & $15.23^{b}$ & $13.91^{\mathrm{b}}$ & $4.77^{\mathrm{a}}$ & $4.60^{\mathrm{a}}$ & $0.76^{\mathrm{b}}$ & $0.71^{\mathrm{b}}$ \\
\hline \multirow{6}{*}{ Times } & $\mathrm{T} 1$ & $40.00^{\mathrm{e}}$ & $36.05^{d}$ & $11.21^{\mathrm{d}}$ & $9.30^{d}$ & $3.60^{\mathrm{c}}$ & $3.92^{\mathrm{c}}$ & $0.65^{\mathrm{d}}$ & $0.47^{\mathrm{c}}$ \\
\hline & $\mathrm{T} 2$ & $66.62^{d}$ & $54.53^{\mathrm{c}}$ & $15.07^{\mathrm{c}}$ & $14.22^{c}$ & $4.42^{b}$ & $3.84^{\mathrm{c}}$ & $0.75^{\mathrm{cd}}$ & $0.67^{b}$ \\
\hline & $\mathrm{T} 3$ & $84.95^{c}$ & $75.24^{b}$ & $17.41^{\mathrm{b}}$ & $14.56^{\mathrm{c}}$ & $4.89^{\mathrm{a}}$ & $5.17^{\mathrm{a}}$ & $0.76^{c}$ & $0.86^{\mathrm{a}}$ \\
\hline & $\mathrm{T} 4$ & $92.13^{b}$ & $78.42^{\mathrm{a}}$ & $17.84^{b}$ & $15.69^{b}$ & $5.19^{\mathrm{a}}$ & $4.99^{\mathrm{a}}$ & $1.04^{\mathrm{b}}$ & $0.87^{\mathrm{a}}$ \\
\hline & $\mathrm{T} 5$ & $97.14^{\mathrm{a}}$ & $79.65^{\mathrm{a}}$ & $18.81^{\mathrm{a}}$ & $17.83^{\mathrm{a}}$ & $5.16^{\mathrm{a}}$ & $4.46^{\mathrm{b}}$ & $1.27^{\mathrm{a}}$ & $1.91^{\mathrm{a}}$ \\
\hline & \multicolumn{9}{|c|}{ F values } \\
\hline PD & & $12.83^{* *}$ & $7.42^{* *}$ & $55.13^{* *}$ & $13.53^{* *}$ & $5.39^{*}$ & $17.06^{* *}$ & $76.60^{* *}$ & $44.54^{* *}$ \\
\hline $\mathrm{T}$ & & $844.49^{* *}$ & $699.31^{* *}$ & $245.33^{* *}$ & $295.74^{* *}$ & $53.04^{* *}$ & $63.61^{* *}$ & $90.05^{* *}$ & $116.54^{* *}$ \\
\hline $\mathrm{PD} \times \mathrm{T}$ & & $12.55^{* *}$ & $19.83^{* *}$ & $5.03^{*}$ & $13.00^{* *}$ & $3.59^{* *}$ & $1.12^{\mathrm{ns}}$ & $0.85^{\mathrm{ns}}$ & $6.82^{* *}$ \\
\hline
\end{tabular}

${ }^{*}$ Means that do not share a letter are significantly different. ${ }^{*} \mathrm{p} \leq 0.05,{ }^{*} \mathrm{p} \leq 0.01$, ns: non-significant PD1: $70 \times 5 \mathrm{~cm}$, PD2: $70 \times 20 \mathrm{~cm}$, PD3: $35 \times 5 \mathrm{~cm}$

\section{Height to node ratio $(\mathrm{HNR})$}

The highest HNR in both years of the experiment was obtained in PD1 (4.72 and 4.63 pcs plant $^{-1}$ ) and PD3 (4.77 and 4.60 pcs plant $^{-1}$ ) treatments. The increase in plant density caused an increase in plant height a consequently to the HNR (Table 3).

The HNR in both years increased proportionally to the increase in the number of days. The HNR in 2006 was ranked from low to high as T1 $(3.60 \mathrm{~cm})<\mathrm{T} 2(4.42$ $\mathrm{cm})<\mathrm{T} 3(4.89 \mathrm{~cm})<\mathrm{T} 5(5.16 \mathrm{~cm})<\mathrm{T} 4(5.19 \mathrm{~cm})$, and in $2007 \mathrm{~T} 2(3.22 \mathrm{~cm})<\mathrm{T} 1$ $(3.92 \mathrm{~cm})<\mathrm{T} 5(4.46 \mathrm{~cm})<\mathrm{T} 4(4.99 \mathrm{~cm})<\mathrm{T} 3(5.17 \mathrm{~cm})$. The HNR peaked in T3 and T4 times, which are the flowering peak and boll development periods, and slightly decreased after the cut-out period. The HNR in this study are coincide with the findings of Birgul (2008) and Celik et al. (2009) who reported that the HNR was 2.6 at the squaring stage, 3.4 at the beginning of flowering, 4.6 at the flowering peak, 5.1 in the cut-out period, 5.04 in the boll opening period and 4.84 in the harvest period. The results can be associated with the consumption of nutrients in the development of more bolls with the formation of flowers and bolls in the generative period after certain vegetative development period. Therefore, plants continue generative development rather than vegetative growth (Kerby et al., 1993).

\section{Stem diameter $(\mathrm{cm})$}

The stem diameter of the plants in the PD2 $(1.11$ and $1.43 \mathrm{~cm})$ treatment was higher in both years of the experiment compared to the other two plant densities. The result can be explained by the fact that plant in wide row plantings benefit from the competitive environment better and the plant uptake and use more nutrients. In both years of the experiment, the stem diameter increased proportionally with the increase in the number of days. The stem diameter of cotton plants by the time was $\mathrm{T} 1<\mathrm{T} 2<\mathrm{T} 3<\mathrm{T} 4<\mathrm{T} 5$, 
respectively (Table 3). Zhang et al. (2016) reported that stem diameter increased as plant density decreased.

\section{Flower dry matter weight (g plant $\left.{ }^{-1}\right)$}

The highest flower dry matter accumulation in both years of the experiment was obtained in PD2 (49.36 and $44.48 \mathrm{~g}$ ) treatment. The decrease in the number of plants per $\mathrm{m}^{-2}$ in wide row plantings improved the utilization of competitive environment and nutrients in plant development. Our results are in agreement with those reported by Khan et al. (2020), who stated that flower dry matter accumulation decreases with the increase in plant density. Similarly, Yang et al. (2014) indicated that accumulation of flower biomass decreased in high and low plant densities.

The flower dry matter accumulation increased proportionally with increase in the number of days (Table 4). The results are similar to the findings of Dai et al. (2015), who reported that dry matter accumulations gradually increased with plant growth. The highest flower dry matter accumulation in 2006 was obtained at T5 time $(82.01 \mathrm{~g})$, while T3 (45.22 g), T4 (41.98 g) and T5 (50.86 g) times were in the same group in 2007. This result reveals that plants produce flower dry matter in proportionally with the progress in generative period. The flower dry matter weight in total dry matter weight in 2006 was ranked as PD1 $(46 \%)>$ PD3 (44\%) > PD2 (37\%) and in 2007, PD2 $(58 \%)>$ PD1 $(55 \%)>$ PD3 $(39 \%)$ (Table 2). In terms of time, the flower dry matter weight in total dry matter weight in 2006 was ranked as T1 $(\% 6)<\mathrm{T} 2(\% 16)<\mathrm{T} 3$ $(\% 40)<\mathrm{T} 5 \quad(\% 46)<\mathrm{T} 4 \quad(\% 47)$; in 2007, T1 $(\% 4)<\mathrm{T} 2 \quad(\% 13)<\mathrm{T} 5 \quad(\% 62)<\mathrm{T} 4$ $(\% 54)<\mathrm{T} 3(\% 69)$. The flowers and boll dry matter accumulation in total dry matter at T3 time $\left(90^{\text {th }}\right.$ day), which coincides with the flowering peak and boll development period, was higher in 2007 compared to the other times examined.

Table 4. The effect of different plant densities and growth times in cotton on flower dry matter weight $\left(\mathrm{g}\right.$ plant $\left.{ }^{-1}\right)$, leaf dry matter weight $\left(\mathrm{g}\right.$ plant $\left.^{-1}\right)$, stem dry matter weight $\left(\mathrm{g}\right.$ plant $\left.{ }^{-1}\right)$ and total dry matter weight $\left(g\right.$ plant $\left.^{-1}\right)$

\begin{tabular}{|c|c|c|c|c|c|c|c|c|c|}
\hline \multirow[t]{2}{*}{ Treatments } & & \multicolumn{2}{|c|}{$\begin{array}{c}\text { Flower dry } \\
\text { matter weight } \\
\left(\text { g plant }^{-1}\right)\end{array}$} & \multicolumn{2}{|c|}{$\begin{array}{c}\text { Leaf dry matter } \\
\text { weight } \\
\left(\text { g plant }^{-1}\right)\end{array}$} & \multicolumn{2}{|c|}{$\begin{array}{c}\text { Stem dry matter } \\
\text { weight } \\
\left(\text { g plant }^{-1}\right)\end{array}$} & \multicolumn{2}{|c|}{$\begin{array}{c}\text { Total dry matter } \\
\text { weight } \\
\left(\text { g plant }^{-1}\right)\end{array}$} \\
\hline & & 2006 & 2007 & 2006 & 2007 & 2006 & 2007 & 2006 & 2007 \\
\hline \multirow{3}{*}{ Plant density } & PD1 & $33.40^{b^{*}}$ & $29.91^{b^{*}}$ & $17.98^{b^{*}}$ & $13.93^{a^{*}}$ & $21.31^{b^{*}}$ & $10.93^{b^{*}}$ & $72.69^{b^{*}}$ & $54.77^{b^{*}}$ \\
\hline & PD2 & $49.36^{\mathrm{a}}$ & $44.48^{\mathrm{a}}$ & $46.05^{\mathrm{a}}$ & $16.01^{\mathrm{a}}$ & $37.11^{\mathrm{a}}$ & $15.85^{\mathrm{a}}$ & $132.52^{\mathrm{a}}$ & $76.34^{\mathrm{a}}$ \\
\hline & PD3 & $33.80^{b}$ & $10.85^{\mathrm{c}}$ & $21.85^{b}$ & $8.73^{b}$ & $21.75^{b}$ & $7.98^{b}$ & $77.40^{b}$ & $27.56^{c}$ \\
\hline \multirow{6}{*}{ Times } & $\mathrm{T} 1$ & $0.85^{c}$ & $0.49^{b}$ & $7.88^{c}$ & $8.32^{c}$ & $5.01^{\mathrm{c}}$ & $3.23^{b}$ & $13.74^{\mathrm{c}}$ & $12.04^{b}$ \\
\hline & $\mathrm{T} 2$ & $6.44^{c}$ & $3.52^{\mathrm{b}}$ & $18.21^{\mathrm{c}}$ & $12.22^{b c}$ & $15.58^{b c}$ & $11.47^{\mathrm{a}}$ & $40.23^{c}$ & $27.21^{\mathrm{b}}$ \\
\hline & $\mathrm{T} 3$ & $41.79^{b}$ & $45.22^{\mathrm{a}}$ & $38.52^{a b}$ & $8.56^{c}$ & $25.12^{b}$ & $11.51^{\mathrm{a}}$ & $105.43^{b}$ & $65.29^{\mathrm{a}}$ \\
\hline & $\mathrm{T} 4$ & $63.17^{a b}$ & $41.98^{\mathrm{a}}$ & $31.94^{\mathrm{b}}$ & $19.20^{\mathrm{a}}$ & $38.00^{\mathrm{a}}$ & $16.07^{\mathrm{a}}$ & $133.11^{\mathrm{b}}$ & $77.25^{\mathrm{a}}$ \\
\hline & T5 & $82.01^{\mathrm{a}}$ & $50.86^{\mathrm{a}}$ & $46.59^{\mathrm{a}}$ & $16.13^{\mathrm{ab}}$ & $49.93^{\mathrm{a}}$ & $15.66^{\mathrm{a}}$ & $178.53^{a}$ & $82.65^{\mathrm{a}}$ \\
\hline & \multicolumn{9}{|c|}{ F values } \\
\hline PD & & $4.84^{*}$ & $17.29^{* *}$ & $40.41^{* *}$ & $24.29^{* *}$ & $16.48^{* *}$ & $15.93^{* *}$ & $2.46^{* *}$ & $12.84^{* *}$ \\
\hline $\mathrm{T}$ & & $43.48^{* *}$ & $21.60^{* *}$ & $25.42^{* *}$ & $23.44^{* *}$ & $38.56^{* *}$ & $16.12^{* *}$ & $15.15^{* *}$ & $26.72^{* *}$ \\
\hline $\mathrm{PD} \times \mathrm{T}$ & & $1.06^{\mathrm{ns}}$ & $4.06^{* *}$ & $4.18^{* *}$ & $5.19^{* *}$ & $2.12^{\mathrm{ns}}$ & $1.21^{\mathrm{ns}}$ & $0.72^{*}$ & $4.35^{* *}$ \\
\hline
\end{tabular}

${ }^{*}$ Means that do not share a letter are significantly different. $* \mathrm{p} \leq 0.05$, $* * \mathrm{p} \leq 0.01$, ns: non-significant PD1: $70 \times 5 \mathrm{~cm}$, PD2: $70 \times 20 \mathrm{~cm}$, PD3: $35 \times 5 \mathrm{~cm}$ 


\section{Leaf dry matter weight ( $g$ plant ${ }^{-1}$ )}

Leaf dry matter accumulation in the PD2 (46.05 and $16.01 \mathrm{~g}$ ) was higher than the other two densities in both years of the experiment. The results indicated that plants benefited better from the competitive environment with the decrease in the number of plants per $\mathrm{m}^{2}$ in wide row plantings and plants utilized the nutrients more efficiently in development. In contrast to our findings, Khan et al. (2020) reported that higher number of plants per unit area in dense planting caused higher vegetative growth and increase in total and vegetative biomass. Leaf dry matter accumulation increased proportionally with the increase in the number of days (Table 4). The highest dry matter accumulation in 2006 was obtained at T5 time (46.59 g) and in 2007 at time T4 (19.20 g). The results revealed that physiological recession period started at T4 time in 2006 due to climate and environmental conditions and it was between T3 and T5 times in 2007. The ratio of leaf dry matter weight in total dry matter weight in 2006 was ranked as PD2 $(35 \%)>$ PD3 $(28 \%)>$ PD1 $(25 \%)$; in 2007 , as PD2 $(39 \%)>$ PD1 $(25 \%)>$ PD3 $(21 \%)$ (Table 2). In terms of the times, the ratio of leaf dry matter weight in total dry matter weight in 2006 was ranked as T1 $(57 \%)>\mathrm{T} 2(45 \%)>\mathrm{T} 5(26 \%)>\mathrm{T} 4(24 \%)>\mathrm{T} 3(8 \%)$, and in $2007, \mathrm{~T} 1(69 \%)>\mathrm{T} 2(45 \%)>\mathrm{T} 4(25 \%)>\mathrm{T} 5(20 \%)>\mathrm{T} 3(13 \%)$.

\section{Stem dry matter weight ( plant $^{-1}$ )}

Stem dry matter accumulation in both years of the trial with PD2 treatment (37.11 and $15.85 \mathrm{~g}$ ) was higher compared to the other two plant density treatments. The results revealed that decreasing the number of plants per $\mathrm{m}^{2}$ in wide row plantings improved the use of the competitive environment, and plants utilized nutrients better in development. The results were contradicting to the findings of Khan et al. (2020) who indicated that the total and vegetative biomass increased with the increase in the number of plants per unit area due to high vegetative growth. The stem dry matter accumulation increased proportionally with the increase in the number of days (Table 4). The highest stem dry matter accumulation in 2006 was recorded at T4 (38.00 g) and T5 (49.93 g), and in 2007, it was obtained at T2, T3, T4 and T5. The stem diameters at T2, T3, T4 and T5 were statistically similar and included in the same group. However, the results revealed that plants entered to the physiological recession period between T4 and T5 due to the climate and environmental conditions. In terms of planting density, the ratio of stem dry matter weight in total dry matter weight in 2006 was ranked as PD1 $(29 \%)>$ PD2 $(28 \%)>$ PD3 $(28 \%)$; in 2007, it was ranked as PD3 $(29 \%)>$ PD2 $(21 \%)>$ PD1 $(20 \%)$ (Table 2). In terms of the times examined, the ratio of stem dry matter weight in total dry matter weight in 2006 was ranked as T2 $(39 \%)>\mathrm{T} 1$ $(36 \%)>\mathrm{T} 4(29 \%)>\mathrm{T} 5(28 \%)>\mathrm{T} 3(24 \%)$; in 2007 , it was ranked as $\mathrm{T} 2(42 \%)>\mathrm{T} 1$ $(27 \%)>\mathrm{T} 4(21 \%)>\mathrm{T} 5(19 \%)>\mathrm{T} 3(18 \%)$.

\section{Total dry matter weight ( $g$ plant $\left.{ }^{-1}\right)$}

The PD2 treatment provided higher total dry matter weight (132.52 and $76.34 \mathrm{~g})$ in both years of the experiment compared to the other two plant densities (Fig. 3). The low plant density increased the use of light, nutrients and water, and consequently the plant growth. In addition, higher number of bolls, flowers, leaves and fruiting branches were formed per plant in low density planting. Therefore, total dry matter accumulation per plant was also increased in low plant density. Similarly, Kerby et al. (1990) reported higher dry matter accumulation under lower number of plant per unit area. In contrast to 
our findings, Ali et al. (2009) indicated that dry matter accumulation increased proportionally with the increase in planting density. Rahman et al. (2013) reported that the dry matter ratio per unit area in a plant density of $30 \mathrm{~cm}$ was $323.32 \mathrm{~g} \mathrm{~m}^{-2}$ which decreased to $257.18 \mathrm{~g} \mathrm{~m}^{-2}$ at a plant density of $50 \mathrm{~cm}$ in soybean. The results attributed to the dry matter production and accumulation in the side branches by encouraging the formation of side branches in low plant densities. The increase in the number of side branches causes increase dry matter content in low plant population compared to the normal plant population and also causes more nodes and fruit formation (Carpenter and Board, 1997). High plant density increases plant total biomass, while the individual biomass of a cotton plant decreases (Khan et al., 2019). The results for vegetative and reproductive dry mass obtained in our study are contradicting to the findings of Afzal et al. (2018) who stated that total dry matter production in low density was $19.32 \%$ lower than high density plantings.

The results showed that total dry matter accumulation increased with the increase in the number of days (Table 4). The dry matter accumulation of the plant in 2006 and 2007 increased proportionally from the vegetative period to the end of the generative period $(\mathrm{T} 1<\mathrm{T} 2<\mathrm{T} 3<\mathrm{T} 4<\mathrm{T} 5)($ Fig. 4).

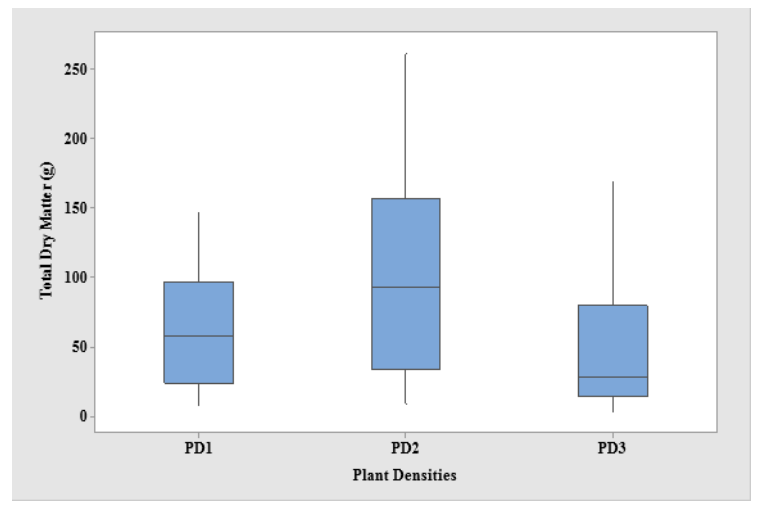

Figure 3. Total dry matter weight at different plant densities

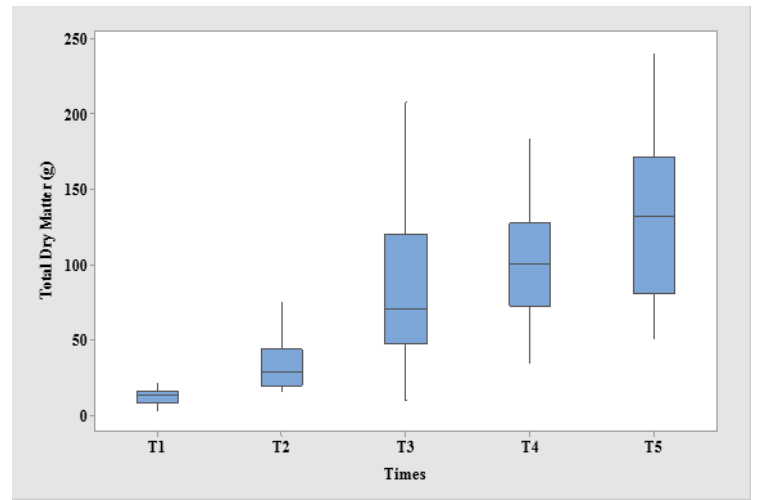

Figure 4. Total dry matter weight at different plant growth times

Daily dry matter production in 2006 between T1-T2 period was $1.77 \mathrm{~g}_{\text {plant }}{ }^{-1}$, between T2-T3 period 4.35 g plant $^{-1}$, between T3-T4 period $1.85 \mathrm{~g}_{\text {plant }}{ }^{-1}$ and between T4-T5 period $3.03 \mathrm{~g} \mathrm{plant}^{-1}$. The daily dry matter production in 2007 between T1-T2 
periods was $1.01 \mathrm{~g}$ plant $^{-1}$, between T2-T3 period $2.54 \mathrm{~g}$ plant $^{-1}$, between T3-T4 $0.80 \mathrm{~g}$ plant $^{-1}$, and between T4-T5 0.36 g plant $^{-1}$. The daily dry matter production in both years of the trial reached the highest level between $\mathrm{T} 1$ and $\mathrm{T} 2$. This can be explained by the highest growth and development of cotton plants, as well as the highest flowering and fruiting development.

\section{Leaf area index (LAI)}

The PD3 (57 plants $\mathrm{m}^{-2}$ ) in both years of the trial produced higher leaf area index (11.55 and 12.66) than other plant density treatments (Fig. 5). Leaf area index ranged from 1.48 to 12.66 .

It can be observed that the leaf area index values increased proportionally from the vegetative period to the end of the generative period $(\mathrm{T} 1<\mathrm{T} 2<\mathrm{T} 3<\mathrm{T} 4<\mathrm{T} 5)$ in both years of the experiment (Fig. 6). Gwathmey and Clement (2010) and Yao et al. (2017) stated that leaf area index increase with the increase in plant density; however, an individual leaf area may be reduced in high plant density.

The LAI in both years increased proportionally with the increase in the number of days (Table 5). The results reported in previous studies are consistent with our findings. For example; Zhang et al. (1962) reported that LAI value reached 6.12 in 400000 plants ha $^{-1}$ plant density, while LAI was 3.82 in 200000 plant ha $^{-1}$ plant density.

Rahman and Hossain (2011) stated that the leaf area index value increased with the increase of plant density. In their research while leaf area index was observed 2.45 per 20 plants $\mathrm{m}^{-2}, 3.69$ per 60 plants $\mathrm{m}^{-2}$. Samani et al. (1999) reported that the leaf area index and dry matter accumulation unit area increased with the decrease of row spacing. Zhang et al. (2016) and Wang et al. (2016) reported that a relatively higher leaf area index (LAI) occurs at higher plant densities.

Table 5. The effect of different plant densities and growth times on the leaf area index (LAI), number of leaves (pcs plant $\left.{ }^{-1}\right)$ and seed cotton yield $\left(\mathrm{kg} \mathrm{ha}^{-1}\right)$

\begin{tabular}{|c|c|c|c|c|c|c|c|}
\hline \multirow[t]{2}{*}{ Treatments } & & \multicolumn{2}{|c|}{$\begin{array}{l}\text { Leaf area index } \\
\text { (LAI) }\end{array}$} & \multicolumn{2}{|c|}{$\begin{array}{l}\text { Number of leaves } \\
\left(\text { pes plant }^{-1}\right)\end{array}$} & \multicolumn{2}{|c|}{$\begin{array}{c}\text { Seed cotton yield } \\
\left(\mathrm{kg} \mathrm{ha}^{-1}\right)\end{array}$} \\
\hline & & 2006 & 2007 & 2006 & 2007 & 2006 & 2007 \\
\hline \multirow{3}{*}{ Plant density } & PD1 & $4.49^{b^{*}}$ & $4.48^{b^{*}}$ & $31.73^{b^{*}}$ & $32.40^{b^{*}}$ & $477.31^{\mathrm{c}}$ & $6010.33^{b^{*}}$ \\
\hline & PD2 & $2.02^{\mathrm{c}}$ & $1.48^{\mathrm{c}}$ & $43.10^{\mathrm{a}}$ & $43.50^{\mathrm{a}}$ & $522.62^{\mathrm{b}}$ & $5294.67^{c}$ \\
\hline & PD3 & $11.55^{\mathrm{a}}$ & $12.66^{\mathrm{a}}$ & $28.43^{\mathrm{b}}$ & $28.31^{\mathrm{b}}$ & $575.90^{\mathrm{a}}$ & $7096.00^{\mathrm{a}}$ \\
\hline \multirow{6}{*}{ Times } & $\mathrm{T} 1$ & $2.64^{\mathrm{d}}$ & $2.23^{\mathrm{c}}$ & $20.50^{c}$ & $21.72^{c}$ & & \\
\hline & $\mathrm{T} 2$ & $5.84^{\mathrm{c}}$ & $6.29^{\mathrm{b}}$ & $33.56^{\mathrm{b}}$ & $33.44^{\mathrm{b}}$ & & \\
\hline & $\mathrm{T} 3$ & $6.82^{\mathrm{b}}$ & $6.48^{\mathrm{b}}$ & $30.61^{\mathrm{b}}$ & $33.66^{b}$ & & \\
\hline & $\mathrm{T} 4$ & $6.94^{\mathrm{b}}$ & $7.66^{\mathrm{ab}}$ & $52.39^{\mathrm{a}}$ & $55.50^{\mathrm{a}}$ & & \\
\hline & $\mathrm{T} 5$ & $7.88^{a}$ & $8.38^{\mathrm{a}}$ & $35.00^{\mathrm{b}}$ & $37.51^{\mathrm{b}}$ & & \\
\hline & & & & $\mathrm{F}$ values & & & \\
\hline PD & & $953.41^{* *}$ & $460.57^{* *}$ & $20.33^{* *}$ & $20.23^{* *}$ & $268.65^{* *}$ & $958.88^{* *}$ \\
\hline $\mathrm{T}$ & & $96.12^{* *}$ & $47.01^{* *}$ & $27.51^{* *}$ & $25.98^{* *}$ & & \\
\hline $\mathrm{PD} \times \mathrm{T}$ & & $25.97^{* *}$ & $15.95^{* *}$ & $2.95^{*}$ & $2.68^{*}$ & & \\
\hline
\end{tabular}

*Means that do not share a letter are significantly different. *p $\leq 0.05, * * \mathrm{p} \leq 0.01$

PD1: $70 \times 5 \mathrm{~cm}$, PD2: $70 \times 20 \mathrm{~cm}$, PD3: $35 \times 5 \mathrm{~cm}$ 


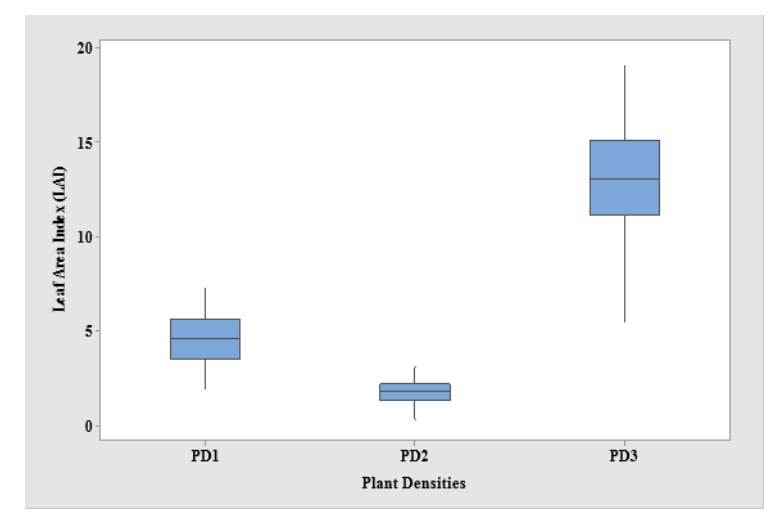

Figure 5. Leaf area index at different plant densities

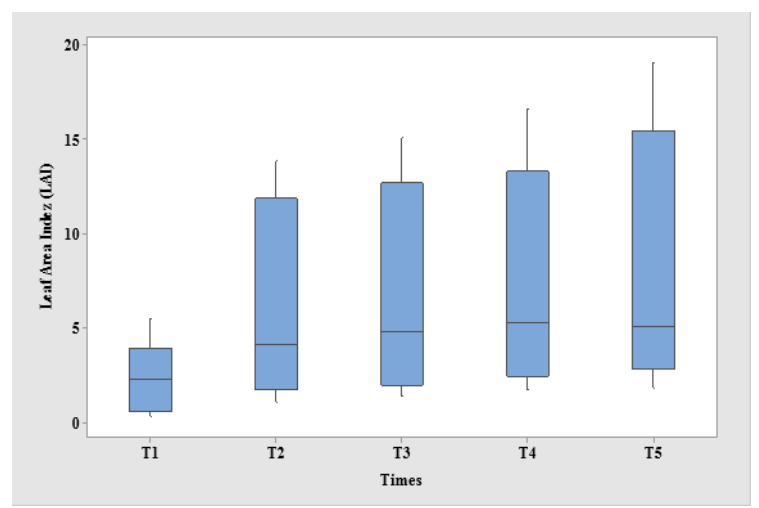

Figure 6. Leaf area index at different growth times

\section{Number of leaves (pcs plant $\left.{ }^{-1}\right)$}

The number of leaves (43.10 and 43.50 pcs plant $^{-1}$ ) in PD2 treatment was higher in both years compared to the other two plant densities (Table 5). Similarly, Khan et al. (2020) stated that the number of leaves per plant is affected by the plant density and the number of leaves decreases with increasing density. In addition, the decrease in the number of plants per $\mathrm{m}^{2}$ in wide row plantings improved the utilization of competitive environment, nutrients were used better in plant development, and thus more leaves were formed. The number of leaves in 2006 from low to high was ranked as T1 $(20.50)<\mathrm{T} 3(30.61)<\mathrm{T} 2(33.56)<\mathrm{T} 5(35.00)<\mathrm{T} 4(52.39)$. In 2007, the number of leaves was ranked as T1 $(21.72)<\mathrm{T} 2(33.44)<\mathrm{T} 3(33.86)<\mathrm{T} 5(37.51)<\mathrm{T} 4(55.50)$. The highest number of leaves in both years of the experiment was obtained at T4 $\left(105^{\text {th }}\right.$ day). Although the number of leaves per plant generally increased from T1 to T4 period, decreased at T5 period. This situation can be explained by the slowing of vegetative development due to physiological maturation and senescence of the plant.

\section{Seed cotton yield ( $\left.\mathrm{kg} \mathrm{ha}^{-1}\right)$}

In both years of the experiment, the yield increased with the increase in the number of plants per $\mathrm{m}^{2}$ (Table 5). The yield in PD3, narrow planting, was higher in both years (5759 and $7096 \mathrm{~kg} \mathrm{ha}^{-1}$ ) compared to the yield recorded in other plant density treatments (Figs. 7-8). 


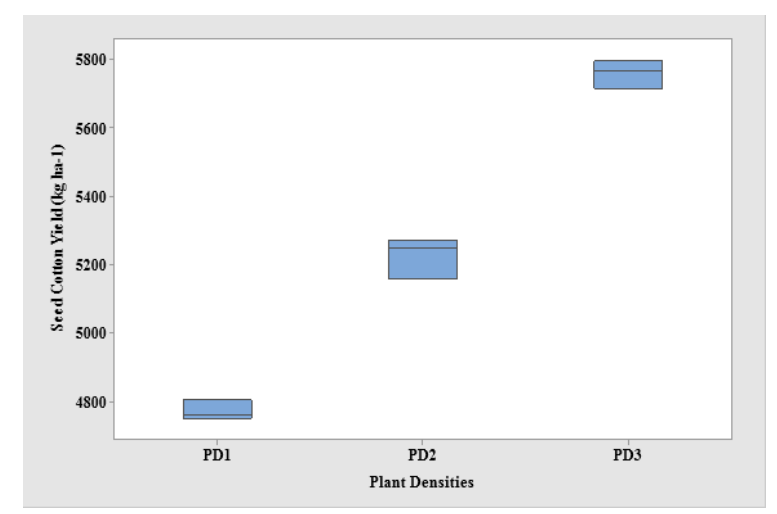

Figure 7. Seed cotton yield at different plant densities $\left(\mathrm{kg} \mathrm{ha}^{-1}\right)$ (first year)

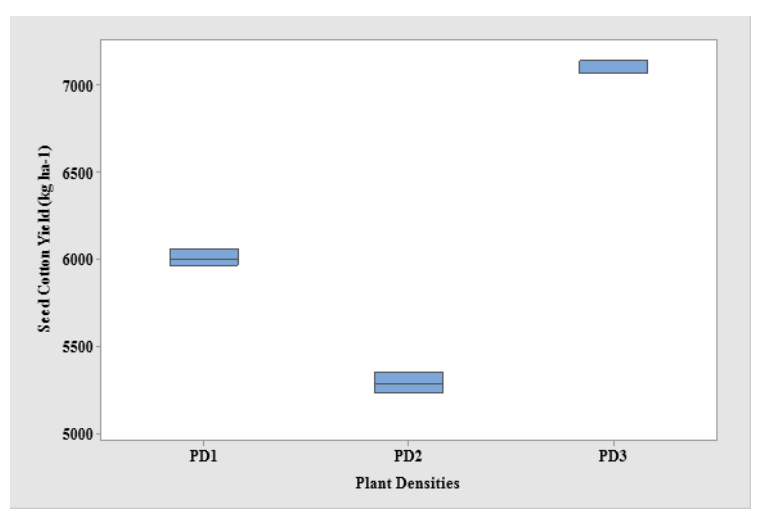

Figure 8. Seed cotton yield at different plant densities $\left(\mathrm{kg} \mathrm{ha}^{-1}\right)$ (second year)

The yield per plant was decreased or the total dry matter accumulation per plant was lower in dense plantings, however, the increase in the number of plants per unit area caused an increase in total yield. The increase in the number of plants in a unit area up to a certain number decreased the yield per plant, however total yield increased.

Zhang et al. (2016) reported that the seed cotton yield (5908, 6158 and $6074 \mathrm{~kg} \mathrm{ha}^{-1}$ ) increased with the increase of plant density $\left(12,18\right.$ and 24 plant $\mathrm{m}^{-2}$ ), which is consistent with our results.

\section{Conclusions}

The results indicated that the growth parameters examined were affected by the plant density treatments tested in the experiment. The PD2 treatment $\left(7\right.$ plants per $\left.\mathrm{m}^{-2}\right)$ caused higher plant height, number of nodes, stem diameter, flower, leaf, stem and total dry matter weights, while PD3 treatment (57 plants per $\mathrm{m}^{-2}$ ) yielded higher LAI and yield compared to the other plant density treatments. The decrease in the number of plants per $\mathrm{m}^{-2}$ in wide row plantings improved the benefit from the competitive environment and increased the use of light, water and nutrients in plant development. However, the increase in the number of plants per unit area had a positive effect on yield. Excessive plant density can cause plants to receive less light, increase in disease and pest populations, and difficulties in planting and especially harvesting. 
Plant density varies from each region to region due to factors such as genetic structure, climate and soil conditions, fertilization, irrigation, cultural practices and harvesting method. Therefore, the most suitable plant density in the regions where cotton is grown should be determined according to the results of the researches

\section{REFERENCES}

[1] Afzal, M. N., Tariq, M., Ahmad, M., Mubeen, K., Khan, M. A., Afzal, M. U., Ahmad, S. (2018): Dry matter, lint mass and fiber properties of cotton in response to nitrogen application and planting densities. - Pakistan Journal of Agricultural Research 32(2): 229-240.

[2] Ali, H., Afzal, M. N., Muhammad, D. (2009): Effect of sowing dates and plant spacing on growth and dry matter partitioning in cotton (Gossypium hirsutum L.). - Pakistan Journal Botany 41(5): 2145-2155.

[3] Anonymous (2007a). GAP Agricultural Research Institute. - Sanliurfa, Turkey.

[4] Anonymous (2007b). Meteorological Data Obtained from Sanliurfa Meteorological Station. - Sanliurfa, Turkey.

[5] Bange, M. P., Milroy, S. P. (2004): Growth and dry matter partitioning of diverse cotton genotypes. - Field Crops 87: 73-87.

[6] Bednarz, C. W., Bridges, D. C., Brown, S. M. (2000): Analysis of cotton yield stability across population densities. - Agronomy Journal 92: 128-135.

[7] Bednarz, C. W., Nichols, R. L., Brown, S. M. (2006): Plant density modifications of cotton within-boll yield components. - Crop Science 46: 2076-2080.

[8] Beyyavas, V., Yilmaz, A., Haliloglu, H. (2018): The effect of different plant densities and mepiquat chloride application on cotton (Gossypium hirsutum L.) yield and yield components in normal sowing time. - Journal of Agricultural Faculty of Mustafa Kemal University 23(2): 262-273.

[9] Birgul, I. H. (2008): Determination of fiber characteristics for different harvesting dates and plant growth parameters in some cotton (Gossypium hirsutum L.) varieties. - Harran University Graduate School of Natural and Applied Sciences Department of Field Crops. MSc. Thesis. Sanliurfa, Turkey.

[10] Board, J. E. (2000): Light interception efficiency and light quality effect yield compensation of soybean at low plant populations. - Crop Science 40: 1285-1294.

[11] Calhoun, D. S., Bowman, D. T., May, O. L. (1997): Pedigrees of Upland and Pima Cotton Cultivars Released between 1970 and 1995. - Division of Agriculture, Forestry and Veterinary, Medicine Communications, Mississippi State University. U.S.A.

[12] Carpenter, A. C., Board, J. E. (1997): Growth dynamic factors controlling soybean stability across plant populations. - Crop Science 37(5): 1520-1526.

[13] Celik, I., Onal, I., Cetinkaya, M. (2009): Evaluation of plant growth characteristics of cotton cultivar Çukurova-1518 by plant monitoring techniques in Antalya conditions. - Derim 26(2): 42-56.

[14] Clawson, E. L., Cothren, J. T., Blouin, D. C. (2006): Nitrogen fertilization and yield of cotton in ultra-narrow and conventional row spacings. - Agronomy Journal 98: 72-79.

[15] Dai, j., Li, W., Tang, W., Zhang, D., Li, Z., Lu, H., Eneji, A. E., Dong, H. (2015): Manipulation of dry matter accumulation and partitioning with plant density in relation to yield stability of cotton under intensive management. - Field Crops Research 180: 207215.

[16] Dong, H. Z., Li, W. J., Tang, W., Li, Z. H., Zhang, D. M. (2006a): Crop/Stress physiology effects of genotypes and plant density on yield, yield components and photosynthesis in BT transgenic cotton. - J. Agron. Crop Sci. 139: 132-139. 
[17] Dong, H., Li, W., Tang, W., Li, Z., Zhang, D., Niu, Y. (2006b): Yield, quality and leaf senescence of cotton grown at varying planting dates and plant densities in the Yellow River Valley of China. - Field Crops Research 98: 106-115.

[18] Gwathmey, C. O., Clement, J. D. (2010): Alteration of cotton source-sink relations with plant population density and mepiquat chloride. - Field Crops Research 116: 101-107.

[19] Harem, E. (2010): Cotton Varieties Registered in Turkey. - GAP Agricultural Research Institute. Publication No: 165. Sanliurfa, Turkey.

[20] Hussain, S., Farid, Z. S., Anwar, M., Gill, M. I., Baugh, M. D. (2000): Effect of plant density and nitrogen on the yield of seed cotton variety CIM-443. - Sarhad J. Agri. 16: 143-147.

[21] Jones, M. A., Wells, R., Guthrie, D. S. (1996): Cotton response to seasonal pattern of flower removal: II. Growth and dry matter allocation. - Agronomy Journal 36: 639-645.

[22] Kaggwa-Asiimwe, R., Andrade-Sanchez, P., Wang, G. (2013): Plant architecture influences growth and yield response of upland cotton to population density. - Field Crops Research 145: 52-59.

[23] Kandil, A. A., Badawi, M. A., El-Moursy, S. A., Abdou, U. M. A. (2004): Effect of planting dates, nitrogen levels, and bio-fertilization treatment on 1: Growth attributes of suger beet (Beta vulgaris L.). - Scietif. J. King. Faisal Uni. 5(2): 227-237.

[24] Kerby, T. A., Cassman, K. G., Keeley, M. (1990): Genotypes and plant densities for narrow-row cotton systems. II. Leaf area and dry-matter partitioning. - Crop Science 30: 649-653.

[25] Kerby, T. A., Keeley, M., Watson, M. (1993): Variation in Fiber Development as Affect by Source to Sink Relationships. - In: Herber, D. J., Richter, D. A. (eds.) Cotton Physiology Conference. Pron. Beltwide Cotton Conf., New Orleans, LA. 10-14 Jan, 1993. Natl. Cotton Counc., Memphis, TN, pp. 1248-1251.

[26] Khan, A., Wang, L., Ali, S., Tung, S. A., Hafeez, A., Yang, G. (2017): Optimal planting density and sowing date can improve cotton yield by maintaining reproductive organ biomass and enhancing potassium uptake. - Field Crops Research 214: 164-174.

[27] Khan, A., Kong, X., Najeeb, U., Zheng, J., Kean, D., Tan, Y., Akhtar, K., Munsif, F., Zhou, R. (2019): Planting density induced changes in cotton biomass yield, fiber quality, and phosphorus distribution under beta growth model. - Agronomy-Basel 9(9): 1-18.

[28] Khan, N., Han, Y., Xing, F., Feng, L., Wang, Z., Wang, G., Yang, B., Fan, Z., Lei, Y., Xiong, S., Li, X., Li, Y. (2020): Plant density influences reproductive growth, lint yield and boll spatial distribution of cotton. - Agronomy-Basel 10(14): 1-17.

[29] Mao, L., Zhang, L., Evers, J. B., Werf, W., Liu, S., Zhang, S., Wang, B., Li, Z. (2015): Yield components and quality of intercropped cotton in response to mepiquat chloride and plant density. - Field Crops Research 179: 63-71.

[30] Montgomery, D. C. (1997): Design and Analysis of Experiments. $4^{\text {th }}$ Ed. - Wiley, New York.

[31] Rahman, M., Hossain, M. (2011): Plant density effects on growth, yield and yield components of two soybean varieties under equidistant planting arrangement. - Asian Journal of Plant Sciences 10(5): 278-286.

[32] Rahman, M. M., Rahman, M. M., Hossain, M. M. (2013): Effect of Row Spacing and Cultivator on The Growth and Seed Yield of Soybean (Glycine max [L.] Merill) in Kharif-II Season. - The Agriculturists 11(1): 33-38.

[33] Reddy, K. R., Reddy, V. R. (1992): Temperature Effects on early season cotton growth and development. - Agronomy Journal 84(2): 229-237.

[34] Ren, X., Zhang, L., Du, M., Evers, J. B., Werf, W., Tian, X., Li, Z. (2013): Managing mepiquat chloride and plant density for optimal yield and quality of cotton. - Field Crops Research 149: 1-10.

[35] Reta-Sánchez, D. G., Flowler., J. L. (2002): Canopy light environment and yield of narrow-row cottons as affected by canopy architecture. - Agronomy Journal 94: 13171323. 
[36] Saleem, M. F., Bilal, M. F., Awais, M., Shahid, M. Q., Anjum, S. A. (2010): Effect of nitrogen on seed cotton yield and fiber qualities of cotton (Gossypium hirsutum L.) cultivars. - J. Anim. Plant Sci. 20(1): 23-27.

[37] Samani, M. R. K., Khajehpour, M. R., Ghavaland, A. (1999): Effects of row spacing and plant density on growth and dry matter accumulation in cotton in Isfahan. - Iranian Journal of Agr. Sci. 29(4): 667-679.

[38] Siebert, J. D., Stewart, A. M., Leonard, B. R. (2006): Comparative growth and yield of cotton planted at various densities and configurations. - Agronomy Journal 98: 562-568.

[39] Silvertooth, J. C., Edmisten, K. L., McCarty, W. H. (1999): Production Practices. - In: Smith, C. W. (ed.) Cotton: Origin, History, Technology, and Production. John Wiley and Sons, Inc. New York, pp. 463-465.

[40] Tariq, M., Afzal, M. N., Muhammad, D., Ahmad, S., Shahzad, A. N., Kiran, A., Wakeel, A. (2018): Relationship of tissue potassium content with yield and fiber quality components of Bt cotton as influenced by potassium application methods. - Field Crops Research 229: 37-43.

[41] Wang, Q., Han, S., Zhang, L., Zhang, D., Werf, W. V. D., Evers, J. B., Sun, H., Su, Z., Zhang, S. (2016): Density responses and spatial distribution of cotton yield and yield components in jujube (Zizyphus jujube)/cotton (Gossypium hirsutum) agroforestry. - Europ. J. Agronomy 79: 58-65.

[42] Wells, R., Meredith, W. R. Jr. (1984): Comparative growth of obsolete and modern cotton cultivars: II. Reproductive dry matter partitioning. - Crop Science 24: 863-868.

[43] Wells, R., Meredith, W. R. (1986): Normal vs. okra leaf yield interactions in cotton. - Crop Science 26: 223-232.

[44] Wullschleger, S. D., Oosterhuis, D. M. (1992): Canopy leaf area development and ageclass dynamic in cotton. - Crop Science 3(2): 451-456.

[45] Yang, G. Z., Luo, X. J., Nie, Y. C., Zhang, X. L. (2014): Effects of plant density on yield and canopy micro environment in hybrid cotton. - Journal of Integrative Agriculture 13: 2154-2163.

[46] Yao, H., Zhang, Y., Yi, X., Zuo, W., Lei, Z., Sui, L., Zhang, W. (2017): Characters in light-response curves of canopy photosynthetic use efficiency of light and $\mathrm{N}$ in responses to plant density in field-grown cotton. - Field Crops Research 203: 192-200.

[47] Zhang, R. Z., Tian, L., Zheng, J. L. (1962): LAI and high-yield properties on soybean. - J. Northeast Agric. Coll. 3: 1-7.

[48] Zhang, D., Luo, Z., Liu, S., Li, W., Tang, W., Dong, H. (2016): Effects of deficit irrigation and plant density on the growth, yield and fiber quality of irrigated cotton. - Field Crops Research 197: 1-9.

[49] Zhi, X. Y., Han, Y. C., Li, Y. B., Wang, G. P., Du, W. L., Li, X. X., Mao, S. C., Lu, F. (2016): Effects of plant density on cotton yield components and quality. - J. Integr. Agric. 15: 1469-1479. 